DOI: $10.17516 / 1997-1370-0804$

УДК $902.21+94(57) " 17 / 19 "+908$

\title{
Reconaissance Researches of Kemerova Village: on the Issue of the Russian Settlement Archaeology of the XVII-XIX Centuries
}

\author{
Aleksei G. Marochkina, Igor’ lu. Uskova, \\ Ivan A. Plats ${ }^{a}$, Sergei A. Vasiutin ${ }^{b}$, \\ Larisa lu. Bobrovab and Alexsandr S. Sizev ${ }^{\mathrm{c} *}$ \\ ${ }^{a}$ The Federal Research Center of Coal and Coal Chemistry SB RAS \\ Kemerovo, Russian Federation \\ ${ }^{b}$ Kemerovo State University \\ Kemerovo, Russian Federation \\ ${ }^{c}$ Historical-cultural and natural Museum-reserve \\ «Tomskaia Pisanitsa» \\ Kemerovo, Russian Federation
}

Received 24.07.2019, received in revised form 20.07.2021, accepted 06.07.2021

\begin{abstract}
The subject of this research is the history, chronology and archaeological artifacts from the Kemerova village (Kemirova, Komarova, Temirova). The research is a part of a scientific topic of exploring Russian settlements in the Tom' River region of the XVII-XIX centuries. The aim of this work is to identify the archaeological layer structure, determine the stages of Kemerovo village site development using stratigraphic data and archaeological objects, to compare the archaeological data with the results of written and cartographic sources.

The archaeological research results showed two archaeological layers well stratigraphically recognizable. The lower archaeological layer contains artifacts of the middle of the XVIII century - the cusp of the XIX-XX centuries. So, it is about pre-industrial rural society' life. The upper layer separated from the lower one by a layer containing some coal dates from the XX century. The artifacts bear witness of how the village was transforming into a industrial township. Comparison of the archaeological data and other historical sources materials highlights the need to find cultural remains of Kemerova village emerging period and a clearer differentiation of the middle of the XVIII-XIX centuries which requires further researches on the site.

The area of use of the received results includes not only the history of Kemerovo but also issues of emergence and development of Russian and other ethnic groups' settlements in the XVII-XIX centuries in the Tom' River basin.

Main conclusions: the received results allow us to determine two periods (pre-industrial and early industrial) in the history of Kemerova village before its inclusion into the territory of
\end{abstract}

(C) Siberian Federal University. All rights reserved

* Corresponding author E-mail address: comcon@yandex.ru, yskov74@gmail.com, ivanplac@yandex.ru, vasutin2012@list.ru, chaika.laraa@mail.ru, asizyov@list.ru 
Shcheglovsk town (Kemerovo since 27 March 1932). It can be suggested that Kemerova village with the other Kemerovo rural settlements (Krasnaia, Shcheglova-Ust'-Iskitim, Kuchukovy Yurty / Ulus-Mozzhukha, Evseeva, Borovaia and others) formed the urban territory. In this context, the role of Kemerova village is not only in using its name for the mine, the train station and, finally, for the city but the early idea of connection of this rural settlement with the «burnt hill», coal deposits (1721) which defined the further industrial potential of Kemerovo.

Keywords: Tom' region, Archeology of the city Kemerovo, Kemerova village, artifacts $18^{\text {th }}-19^{\text {th }}$ century.

Research area: history \& archeology

Citation: Marochkin, A.G., Uskov, I. Iu., Plats, I.A., Vasiutin S.A., Bobrova L. Iu., Sizev A. S. (2021). Reconaissance Researches of Kemerova Village: on the Issue of the Russian Settlement Archaeology of the XVII-XIX Centuries. J. Sib. Fed. Univ. Humanit. soc. sci., 14(8), 1154-1166. DOI: 10.17516/1997$1370-0804$

\title{
Рекогносцировочные исследования деревни Кемерово: к проблеме археологии русских сельских поселений XVII-XIX BB.
}

\author{
А.Г. Марочкина, И.Ю. Усков ${ }^{\mathrm{a}}$, И.А. Плаца, \\ С.А. Васютин ${ }^{6}$, Л.Ю. Боброваб, А.С. Сизёв ${ }^{8}$ \\ аФедеральный исследовательский иеентр угля \\ и углехимии СО РАН \\ Российская Федерация, Кемерово \\ ${ }^{\sigma}$ Кемеровский государственный университет \\ Российская Федерачия, Кемерово \\ ${ }^{6}$ Историко-культурный и природный музей-запаведник \\ «Томская писанииа» \\ Российская Федерация, Кемерово
}

\begin{abstract}
Аннотация. Предметом исследования является история, хронология и археологические артефакты деревни Кемерово (Кемеровой, Кемерова, Комарово, Кемірова, Темирова). Исследование представляет собой часть научной темы по изучению русских сельских поселений Притомья XVII-XIX вв. Цель работы - выявить структуру культурного слоя, определить по стратиграфии и археологическим предметам этапы развития памятника деревня Кемерово, сопоставить данные археологии с результатами изучения письменных и картографических источников.

Результаты археологических изысканий показали наличие двух культурных слоев, хорошо выделяющихся с точки зрения стратиграфии. Нижний культурный слой, в котором представлены артефакты середины XVIII в. - рубежа XIX-XX в. Следовательно, он связан с жизнью доиндустриального деревенского сообщества. Верхний культурный слой, отделяющийся от нижнего слоя прослойкой с угольными вкраплениями, относящейся к первой трети XX в. Артефакты свидетельствуют
\end{abstract}


о превращении деревни в шахтерский рабочий поселок. Сравнение археологических данных с материалами других исторических источников указывают на необходимость выявления культурных останков начального периода возникновения деревни Кемерово, и более четкой дифференциации материалов середины XVIII-XIX вв., что требует дальнейших исследований на территории памятника.

Область применения полученных результатов включает не только историю города Кемерово, но вопросы возникновения и развития сельских поселений русских и других этнических групп в XVII-XIX вв. в бассейне p. Томи.

Основные выводы: полученные результаты позволяют выделить два периода (доиндустриальный и ранний индустриальный) в истории деревни Кемерово до ее включения в черту города Щегловска (с 27 марта 1932 г. Кемерово). Можно предположить, что деревня Кемерово наряду с другими «кемеровскими» сельскими поселениями (Красная, Щеглова - Усть-Искитим, Кучуковы юрты / Улус-Мозжуха, Евсеева, Боровая и др.)) сформировали городскую территорию. В этом контексте роль деревни Кемерово определяется не только перенесением ее названия на рудник, железнодорожную станцию и в конечном итоге на город, но и ранним формированием представлений о связи этого сельского поселения с «горелой горой», угольными залежами (1721 г.), определившими в дальнейшем промышленный потенциал города Кемерово.

Ключевые слова: Притомье; археология города Кемерово, деревня Кемерово, артефакты XVIII-XIX вв.

Научная специальность: 07.00. 00 - исторические науки и археология

\section{Introduction}

Questions of archaeological research of the Russian rural and urban settlements in the Tom' River region in the XVII-XIX centuries have been risen several times in scientific literature. The researches in Tomsk territory, where archaeological study started in the XIX century, can serve a role model. The excavations of Tomsk fortress and voivode's house (Chernaia, 1992; 1997; 2015) are well known. On the territory of Kuzbass, the first studies were conducted in 1930-s in Kuznetsk Ostrog (fortress) area which has been excavated several times since that time. The surveys and studies of Novokuznetsk archaeological sites resulted in numerous findings of the XVII-XIX centuries (Shirin, 1993; 2000; 2003; 2006; 2012; 2015 et al.). In the second half of 1970-s - 1980-s in the area of planned Krapivinskyi hydroelectric power station reservoir, settlements with layers of different periods including Russian period layers Saltymakovo III, Glinka, Lachinovo I and others were found (Okuneva, 2006). During the last decades, the Tom' River region Russian settlements studies became regular which resulted in finding of a range of sites with layers of the XVII-XIX centuries Zhurgavan' I, Beregovaia I, Pisannaia II, Ivanovka I, Kulakovo II and III, Bondareva Gora and others (Ziniakov, Bashtannik, Sokolov, Savel'eva, 2009; Shirin, 2010; 2012; 2013; 2015; Marochkin, German, 2011; Marochkin, Plats, Kononchuk, 2015; Marochkin, Iurakova, Shcherbakova, Plats, Fal'man, Kononchuk, Veretennikov, 2015; Marochkin, Sizev, Plats, Kononchuk, 2017; Marochkin, Iurakova, Plats, Sizev, Veretennikov, Kononchuk, Shcherbakova, Minina, Fal'man, 2018; Sizev, 2017; Sizev, Plats, 2018 et al.).

\section{Statement of the problem}

In spite of considerable achievements in the researches of the Russian population in the Tom' River region of the XVII-XIX centuries, the territory of Kemerovo was practically archaeologically unknown which made a big difference with the situation in Novokuznetsk and Tomsk. Besides some occasional findings made by local people, illegal «black» archaeologists, there were no legal excavations in Kemerovo until 2018. Only in 2018, according to the first Permit for archaeological surveys 
in Kemerovo, some material was collected on the territory of the Russian villages known from historical documents of XVIII, and reconnaissance excavations were conducted on the territory of Kemerova village (Kemirova, Komarova).

\section{Methods}

The study of the cartographic materials of 1736 and 1827 allowed us to identify the borders of Kemerova (Komarova) village in late 1820 -s and its internal planning. The layer by layer (conventional horizons) fixation of findings in resonaissance digs allowed us to attribute the artifacts to different periods of the settlement. Comparative and typological study and analogy method allowed us to date some household items (first of all the ware).

\section{Kemerova village}

The name of the settlement of Kemerova (Kemirova, Temirova, Komarova) was first mentioned in the diary note of 28 April 1721 of a German naturalist, researcher of Siberia D. G. Messerschmidt. The note was made in Tomsk by Ph.J. Strahlenberg, a Swedish captive officer who followed the naturalist: «We have heard from lieutenant Ehnberg... between Komarova and Krasnaia village there must be coal» (Messerschmidt, 1962: 93).

This coal deposit (upper the river Tom' seven versts $(7.47 \mathrm{~km})$ from Verkhotomskii Ostrog, «red burnt hill» twenty sazhens high (42.6 $\mathrm{m})$ will be studied and a mineral sample will be taken on 11 September 1721 by P. Pruftzen's expedition according to the order by Mikhailo Volkov, a Cossack's son from Tobolsk (Perevalov, 2003: doc. 7).

So the first form of the toponym is Komarova. Members of the Second Kamchatka expedition of S.P. Krasheninnikov and G. F. Müller of 1734 mention a new form of the toponym: «The red rock on the same side from Shcheglakova village in 4 [versts] $(4.27 \mathrm{~km})$. This rock's length is 1 verst $(1.067 \mathrm{~km})$. At its edge there is Kemerova village, 1 [verst] $(1.067 \mathrm{~km})$ from Shcheglakova»; "Kemerova is 8 verst (8.54 $\mathrm{km}$ ) from the ostrog on the Eastern side [of the Tom'] at the creek of the river Akaeva; Shcheglova or Krasnoiarskaia, on the Eastern side, 1 verst $(1.067 \mathrm{~km})$ from the previous one» (Elert, 1988: 94).

On the «Map of Tomsk and Kuznetsk uezds (regions)» made by the land-surveyor V. Shishkov in 1736, the village is named as v. Kemirova (Fig. 1).

In spite of the fact that later «Kemerova» will become the main toponym form (first of all, in registration records and lists of settlements), the works of geologists and some cartographic sources of the late XIX - early XX centuries show a stable tradition of naming the village with the first toponym form (see examples in: Kovtun, 2012: 25). The toponym form of Temirova is an example of folk etymology and connected to the specific to the Russian dialects switching of guttural consonants to mesiopalatal ones, in particular, from $K$ to $T$.

Sources contain also different hydronims for the water source near the village. As mentioned above, G.-F. Müller pointed the location of the settlement at the river Akaeva, which was mentioned in some sources later. However, the river Alykaevka (correct name) flows to the river Tom' a little bit lower, and Kemerova village was situated on the river Krutoi separating now Rudnichnyi and Kirovskii districts of Kuzbass capital city.

Direct data about the village founders haven't been found. According to V.A. Mogilnikov, it was a farmworker Afanasii Stepanovich Kemirov (born in 1693, died before 1742) (Mogil'nikov, 1993: 127). His father, a plougher of Verkhotomskyi Ostrog Stepan Kemirov, is mentionned in «farm worker» books for 1682-1706. However, according to I. V. Kovtun, the first form of toponym allows us to suggest that the settlement could be founded by M. Volkov's team-mate, ore specialist Fiodor Komarov/Komar (Kovtun, 2012: 32). In «Tomsk Uezd Inventory Revision Book» of 1703, among farm workers-»ssent people» of Verkhotomskii Ostrog who «live in the town suburb and do work and handmade things for a living and pay to the Tsar some amount of bread-corn instead of desiatina (land measure equivalent to 2.7 acres)» was «Fiodor Kamar, single, pays with a quarter of rye, oatmeal as well» $»^{1 .}$

RGADA. Fund 214. Inv 1. File 1371. Sheet 536. 


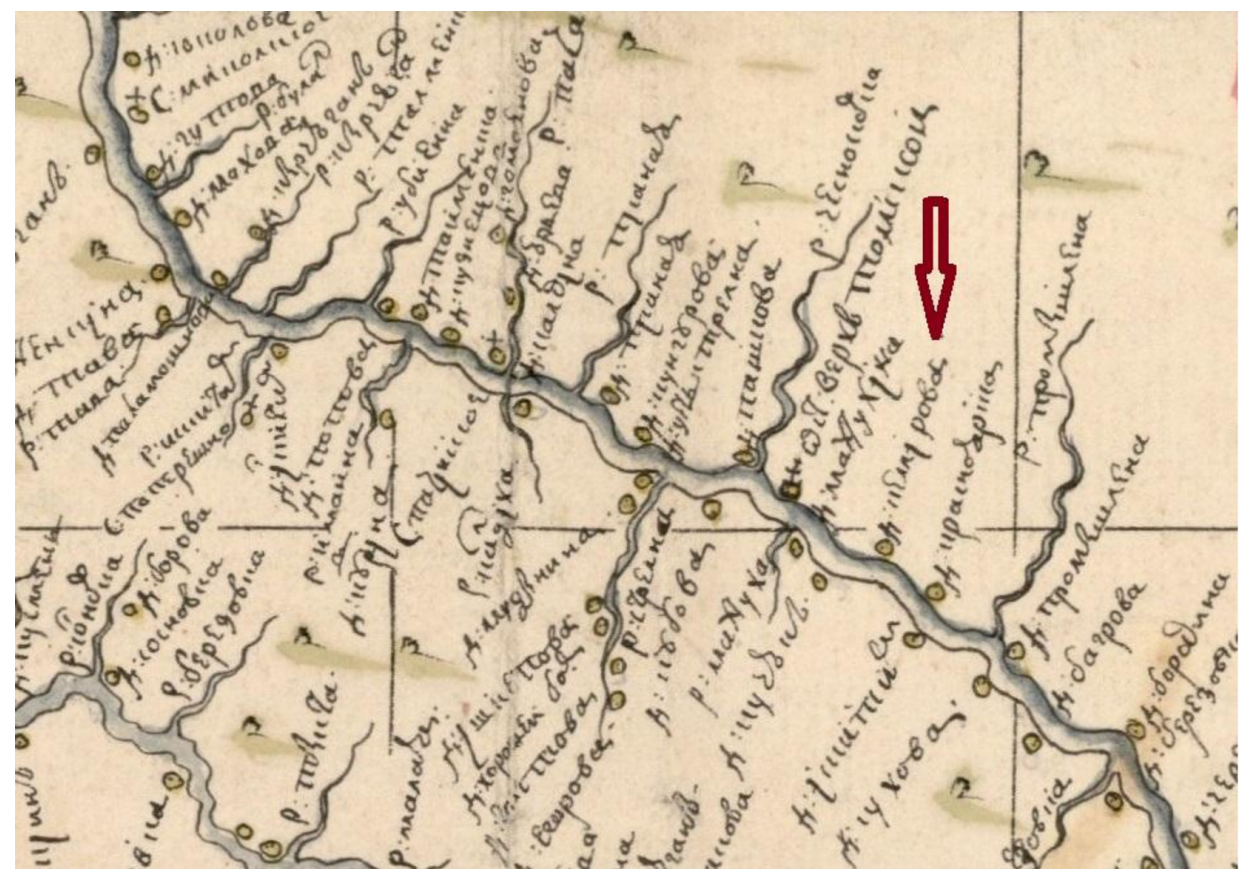

Fig. 1. Exstract from «Map of Tomsk and Kuznetsk uezds» by the land-surveyor V. Shishkov (1736) (State Archive of the Sverdlovsk region). Fund 59. Inv 3. Sheet 1765) with mentioning of Kemirova village

According to the order from 22 June 1759, Tomsk Uezd farm workers including Kemerova village ones were assigned to KolyvanoVoskresenskii mining plant. According to the administrative and territory reform of 1782 , the settlements of Verkhotomskaia sloboda (district) were handed over from Tomsk uezd to Kuznetsk uezd (Uskov, 2011: 59).

In the second half of the XIX century, a new stage of the history of this place begins. The development of Siberian industry, in particular, steam navigation made the need in solid fuel constantly grow. In August of 1878, in order to check if the rumors about illegal coal mining near Kemerova village were true, a mining engineer Bogdanov was sent there, and he reported that local farm workers mined coal to sale it in Tomsk (Uskov, 2011: 111). In spite of further prohibition, they continued coal mining.

After approving «The Regulations for a private coal mining industry in Altai County», the rural society of farm workers in Kemerova village received a part of land for solid fuel mining (the rest three parts of land with coal were given to private actors. The conditions were very favorable with no payment to the owner of the deposit. The farm workers-miners had to follow the regulations of mining work. However, these regulations were not followed and already the following year, the private industry regulations function was ceased and the parts of land with coal were taken back (Mamontov, 1910: 19-31).

Only in 1907, the General Administration of Altai County started industrial coal mining. On 28 August (10 September of the Gregorian calendar) the first mine was founded at Kemerova digging pit (Mamontov, 1910: 43). This date is considered to be the date of Kemerovskii mine foundation. The following development of the mine is connected to the Kopikuz Stock Company (1912-1919), and Kuzbass Autonomous Industrial Colony (1922-1926). In January 1928, Kemerova village became an industrial township, and at the end of the same year was included into the Shcheglovsk town boundaries together with Kemerovskii mine (Uskov, 2011: 200). 


\section{Archaeological researches}

In spring of 2018, reconaissance excavations were conducted on the cape of the Krutoi stream's right bank at its junction with the river Tom' (Fig. 2). The choice of the location of study is based first of all on the cartographic materials and written sources, which determine the creek area as the location of the first Russian settlement in the first half - middle of the XVIII century. Kemerova land survey plan of 1827 locates residential and household buildings at this precise place (Fig. 3). The second reason was the fact that nowadays, the chosen place was partly free of the dense private houses development of Kirovskii district of Kemerovo.
The anthropogenic impact on the site can hardly be overestimated - annual plowing to grow gardens, periodic building some constructions, earth and asphalt roads. However, at the same time, private low-rise houses construction of this part of Kirovskii district preserves to some extent the cultural layer of the historical settlement protecting it from a complete destruction in case of major urban construction work.

During the first inspection of the location on exposed surfaces and ploughland, some material including 41 items was collected. Some fragments of factory made porcelain dishes and glazed pottery were found in single pieces. The biggest part of collected objects presents

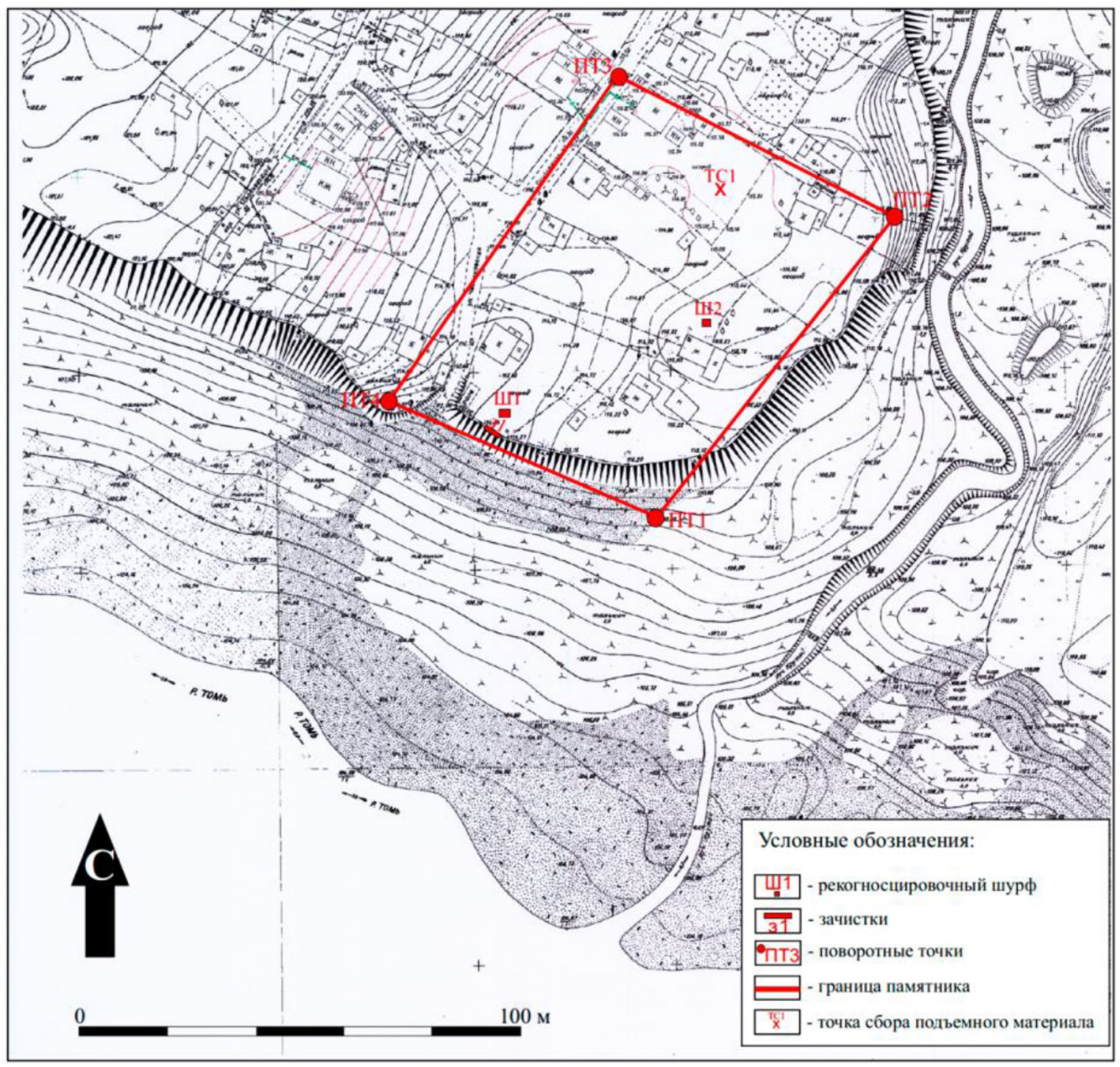

Fig. 2. Map of the explored section in the current topographic state 


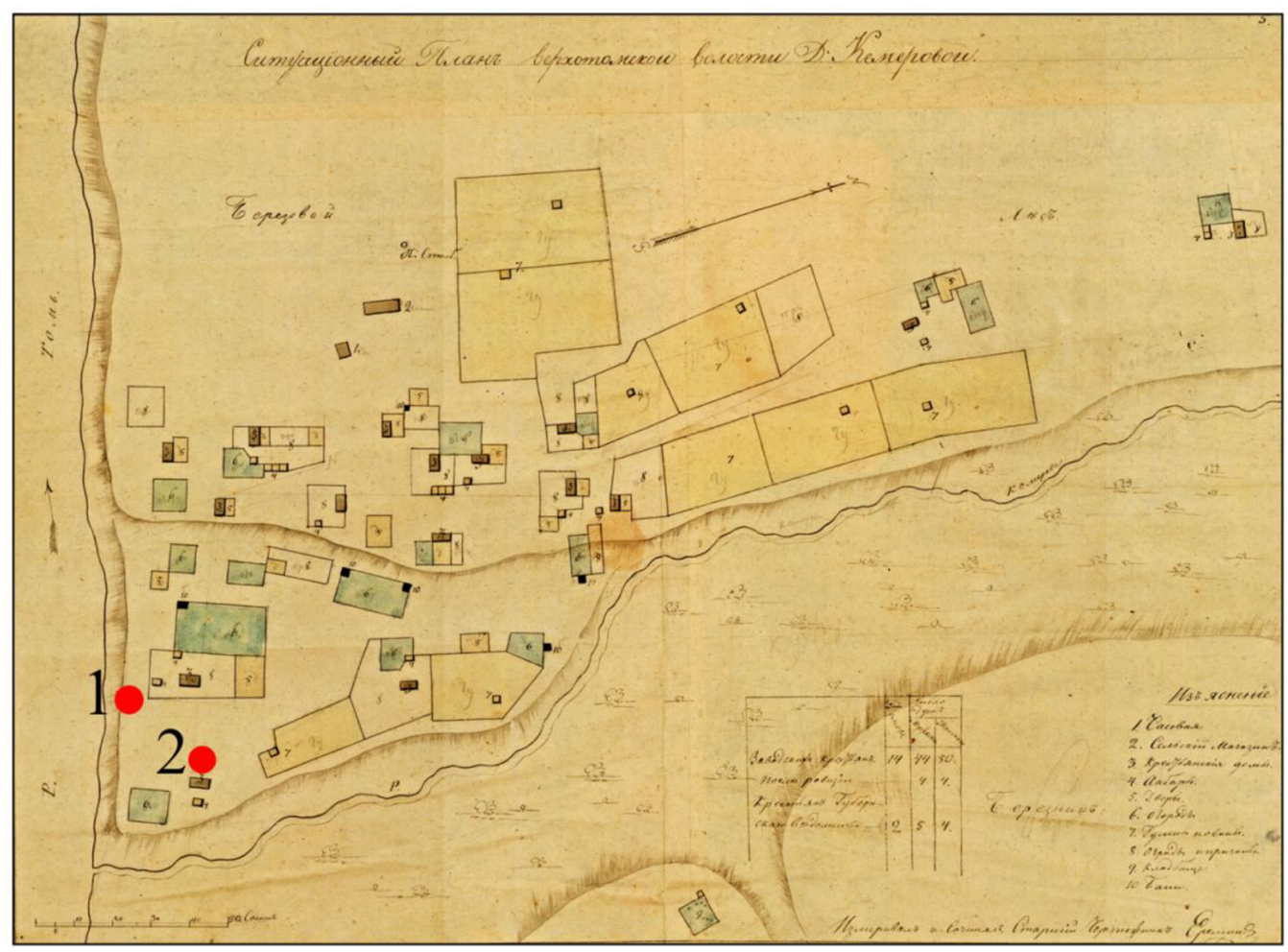

Fig. 3. Kemerova land survey plan after 1834 with archaeological studies locations in 2018

Russian pottery fragments made on a potter's wheel without glaze and pattern. Locals provided us coins found in different periods during earthwork. This proves that some parts of the cultural layer of the XVIII-XIX centuries settlement were preserved.

In 2018, a river bank test rabotage and earth breaking for two reconaissance excavations with surface of $6 \mathrm{~m}^{2} \times 4 \mathrm{~m}^{2}$ were done. Obtained data are enough to specify the stratigraphic and archaeological context of the artifacts in terms of their periodization.

The stratigraphic situation in different parts of the site is completely similar (Fig. 4). It should be noticed that its «purest» and representative form was found during the test rabotage of the river bank. With distance from the river bank, formed layer sequence partly destroyed by household pits of the XX century which is well seen on the stratigraphic sondage profiles.

Stratigraphy of the test rabotage No 1:

1) Poor sod with parts of vegetable soil and roots of vegetations - less than $1 \mathrm{~cm}$ thick.
2) Dark-gray humus clay loam soil with numerous droplets of yellow clay loam, small glass, break-stone, and brick fragments up to $20 \mathrm{~cm}$. It lay at the depth from $1 \mathrm{~cm}$ along all rabotage surface.

3) A layer of coal crumbs - up to $0.7 \mathrm{~cm}$. It was between the layer No 1 and No 3 at depth $20-22 \mathrm{~cm}$. It is fixed along all rabotage surface.

4) Brown humus with high content of vegetable soil - up to $45 \mathrm{~cm}$ thick. It occupied all rabotage surface at depth $20 \mathrm{~cm}$ and more from the modern daylight surface. The layer was formed during manuring and composting by villagers. In the eastern part of the rabotage surface in this layer a pit $35 \mathrm{~cm}$ large and $45 \mathrm{~cm}$ deep was found.

5) Dark-gray humus sand clay with rare inclusions of small gravels - up to $52 \mathrm{~cm}$ thick. It occupied all rabotage surface at the depth 55 and deeper. This layer is similar to the layer No 1 , but the color of the soil is lighter.

6) Yellow «bed-rock» clay-loam soil - it laid at the depth $105-110 \mathrm{~cm}$. 

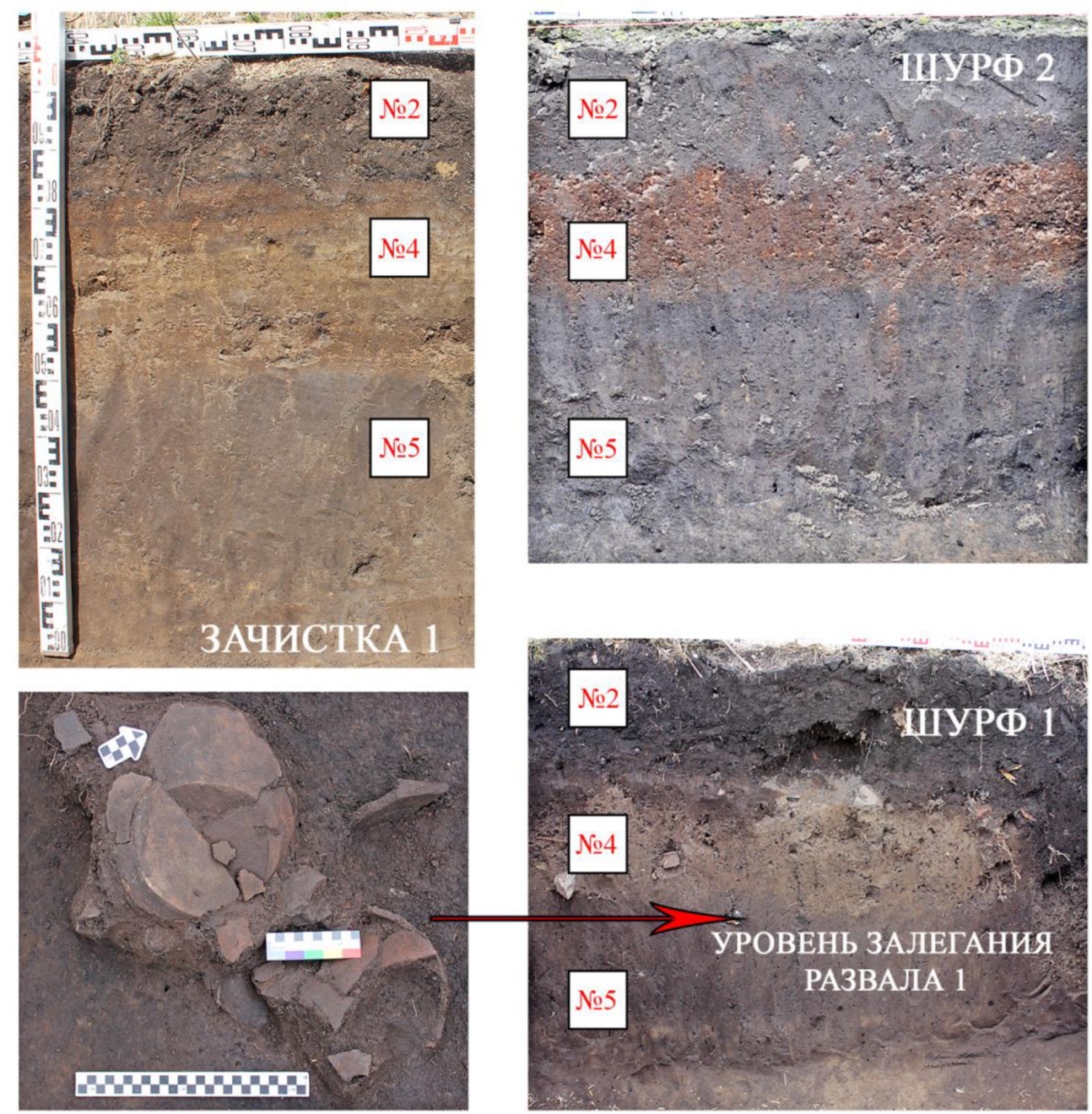

Fig. 4. Stratigraphic summary table - photos of test rabotage and sondage walls with layer explanation

So, the stratigraphic base of the site are the layers 2, 4, 5, 6, but their archaeological density is different.

The layer No 2 which besides filling the later pits, mostly contains objects of the XX century (wire nails, 1930-s - 1940-s coins, a coal mining token etc), with some single earlier ceramics.

The layer No 4 contains a massive amount of non-glazed pottery with rare forged iron objects.

The layer No 5 is archaeologically sterile except for a single fragment of a ceramic vessel edge decorated with a comb pattern (appeal- ingly, more ancient). Test excavation of the layer No 6 didn't result in any artifacts.

The chrono-stratigraphical principle is well shown in the trend of distribution of non-glazed pottery in the first sondage in the conventional horizons $20 \mathrm{~cm}$ thick (Diagram 1).

The diagram shows the clear correlation of this most massive category of findings with the layer No 4 which has the same depth as $4-5$ conventional horizons. A broken ceramic vessel found in situ on the lower boundary of the layer No 4 in the first sondage serves an evidence of this. 4). 


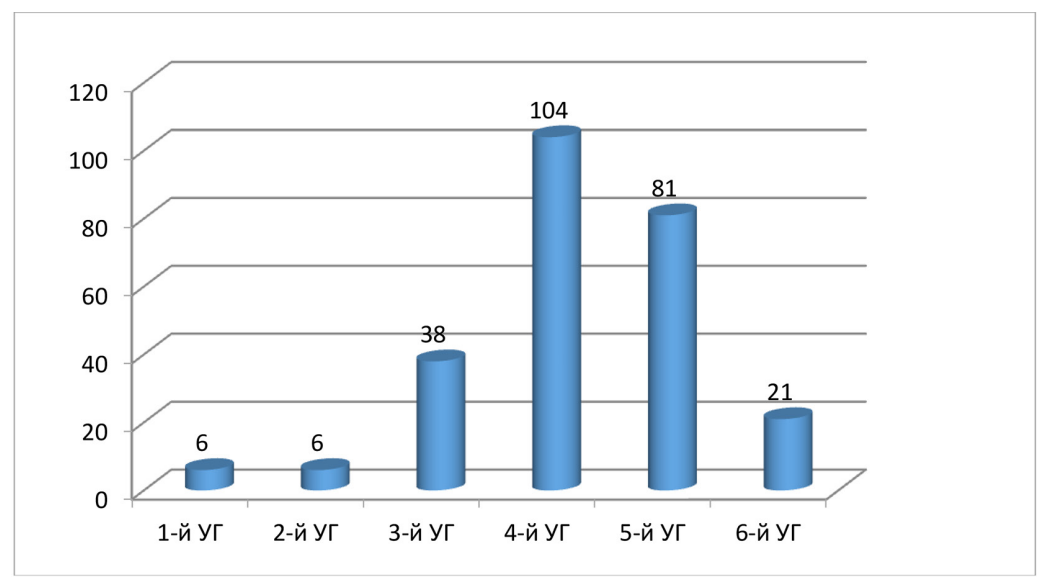

Diagram 1

\section{Artifact assemblage \\ of the XX century (Fig. 5).}

1. Porcelain saucers fragments -5 pces. A fragment from the test rabotage No 1 has a manufacturer's stamp - $\rangle|\mathrm{fz}\rangle-$ Leningrad Lomonosov Porcelain Factory The color and specific lettering of the stamp allowed us to identify that the objects with such stamps were manufactured in 1950-s.

2. Iron thimbles -2 pces. Both objects are severely rusted.

- A thimble of a regular trapezoidal shape with a flat top. Dimentions: $2 \times 2 \mathrm{~cm}$.

- A thimble of a conical shape with a round top and numerous prick marks. The inner surface is threaded. Dimensions: $2 \times 2.4 \mathrm{~cm}$.

3. Domino - 1 pce. Made of wood and covered with red varnish. Dimensions: -3.7 x 2.4 $\mathrm{x} 0.7 \mathrm{~cm}$

4. Coins -3 pces:

- 1 kopeck coin of 1930-1 piece.

- 10 kopecks coin of 1945-1 piece.

- 5 kopecks coin of 1945-1 piece.

5. Coal mining token -1 pce. The token is of a round shape $3,5 \mathrm{~cm}$ in diameter. It has a hole to be hung. The front side has some impressions: «K. R.» (Kemerovskii rudnik - Kemerovskii mine), «DOWN», «1171», «A.I. K.» (Autonomous Industrial Colony). Number 1171 must be the token number. Above this impression, there is another bigger one - a number «4» which must be the number of the mine or the face.
Those objects were used in 1920-s at Kemerovskii mine located nearby, where a large part of Kemerova people worked.

\section{The artifact assemblage of the middle of the XVIII - late XIX centuries. (Fig. 6).}

Fig. 6. Summary table of the objects from the early assemblage of the XVIII-XIX centuries (coins from accasional collections, ceramics)

1. Forged iron nails -2 pces. Found during the sondage No 1 at the boundary of the layer No 4. Both objects were up to $10 \mathrm{~cm}$ long, with rectangular cross-section and massive head.

2. Copper belt buckle frame -1 pce. Found during the sondage No 2 (layer No 4). The object is of a trapezoidal shape, no prong. Dimensions: $-3.5 \times 3 \mathrm{~cm}$

3. Russian glazed ceramics fragments -9 pces. Found in rabotage and during both sondages (layers 3,4). Only body fragments were found, so it is impossible to determine the morphology of this group. The glaze color varies from brown to green. Wall thikness: 0.7-0.9 $\mathrm{mm}$.

4. Black polished ware -1 bottom fragment found during the sondage No 1 (layer No 4). It has a specific gloss and marks of one direction polishing movements on the external and internal surface. Black color. Wall thickness $-1.1 \mathrm{~cm}$.

5. Non-glazed pottery - 311 fragments of bodies and edges. They were found in all three 

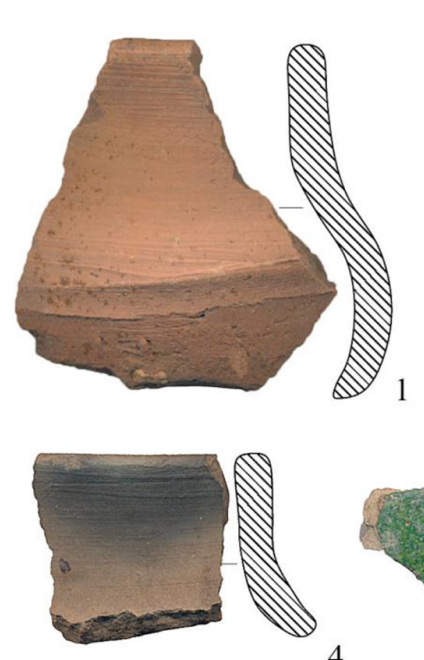

4

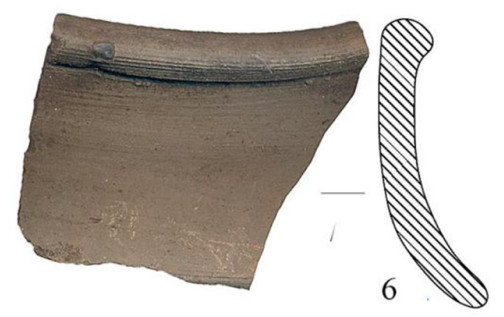

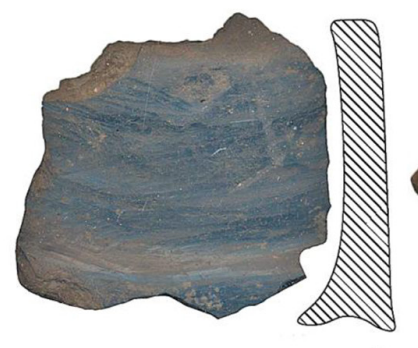

2
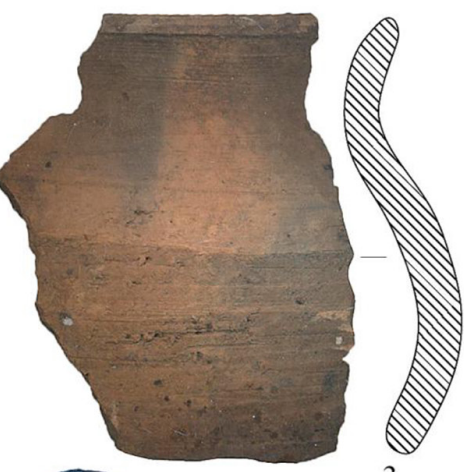

3
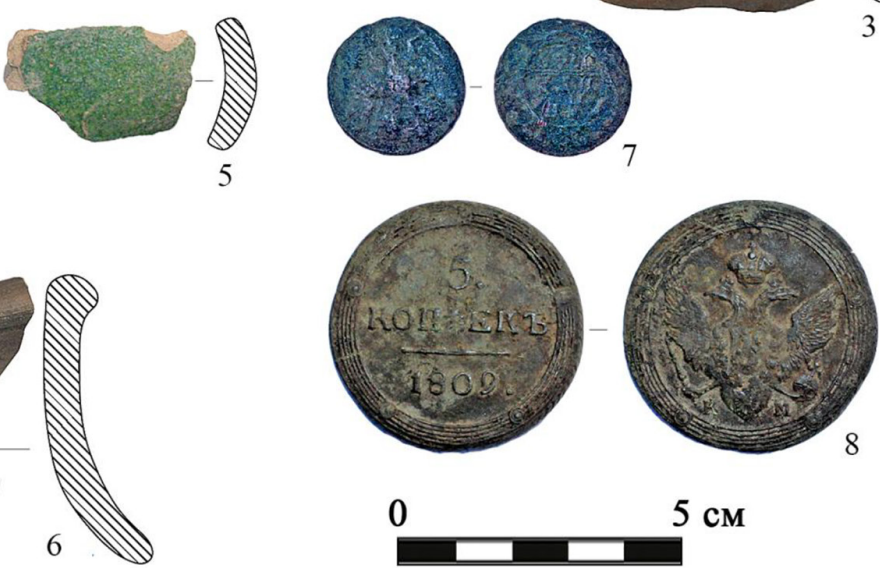

Fig. 5. Summary table of the objects from the late assemblage of the XX century (coins, token, porcelain, dominoes)

archaeological exposures but mostly during the sondage No 1 (layer No 4). According to the fragments, all ware of this group is tall profiled flat-bottomed vessels with straight and folded edge. They all were made on a potter's wheel which is proved by specific marks of one direction polishing movements on the external and internal surface. The color of paste on fracture is brown or black. Wall thickness varies from 0.7 to $1.1 \mathrm{~cm}$.

\section{Discussion}

The artifact assemblage (XVIII-XIX centuries) excavated or occasionally found by locals reflects well established manufacturing and every day life structures in Kemerova village. The earliest date for this settlement which has been archaeologically proved so far is the middle of the XVIII century. An earlier layer (if any) corresponding to the time of foundation and the first decade of Kemerova village can be discovered only in further archaeological studies.

Furthermore, dating of the objects of the middle - second half of the XVIII century is complicated by the fact that besides coins and black polished ware, other findings can be from the second half of the XVIII century as well as the first half or the last quarter of the XIX century. Researchers (see Shirin, 2003; 20062015; Sizev, 2017; Marochkin, Iurakova, Plats, Sizev, Veretennikov, Kononchuk, Shcherbakova, Minina, Fal'man, 2018) have not determined clear criteria to distinguish Russian settlement material of the XVII-XIX centuries more in detail based on particular chronological assemblages.

\section{Results}

In conclusion, we should take note of multiple mentioning of the village of Kemerova (Kemirova, Komarova) in sources of the first 
half of the XVIII century. If the village foundation date is polemic and can be conventionally outlined by the first decade of the XVIII century, the existence of an established settlement in 1721 is beyond question.

The results of the archaeological excavations allow us to make the following conclusions:

1) The site contains at least two archaeological layers which differ in morphology and artifact chronology. The difference in color of the upper and lower parts (layers No 2 and No 4) depends on the amount of vegetable soil which is high in the pre-industrial period and much lower since the moment when the village becomes an industrial township of Kemerovskii mine. The change of the economic set-up was very quick which can explain well the clear border between the layers in some parts highlighted with a layer of coal crumbs.

2) The artifacts from the layer No 4 definitely belong to the Russian population of the village of the XVIII - the beginning of the XX centuries. On the territory of the Middle Tom' River several sites with similar materials have been explored and excavated: Saltymakovo III, Azhendarovo II, Glinka, Lachinovo I, Kuria IVa, Sosnovka IV, Prorva II, Arsenal'skoe I, Bedarevo II, Erunakovo II, Beregovaia I, Zhur- gavan' I, Pisanaia II, Ust'-Nikolskaia I, Ivanovka I etc. [Okuneva, 2006: 15; Shirin, 2015: 15; Ziniakov, Bashtannik, Sokolov, Savel'eva, 2009: 243-244; Marochkin, German, 2011: $82-83$ et al.]. The specificity of the ceramic assemblage of Kemerova village consists in simple pottery without decoration. It is noteworthy that it contain a small amount of glazed, polished or decorated ware.

3) The question of the internal periodization of Kemerova village early assemblage is still open. The precise dating of found objects, in particular the distinguishing of the XVIII and XIX centuries artifacts can be possible only for numismatic materials. Such differentiation of mass ceramic ware cannot be possible for uniformity of type and sameness of Russian pottery during the whole mentioned period. However, black polished ware fragments with coins found earlier justify dating of a part of the early assemblage of the middle - second half of the XVIII century.

Historical and cultural importance of Kemerova village as an archaeological site has been confirmed by the Order No 204 of the Committee of Protection of Cultural Heritage objects of Kemerovo Region from 5 December 2018 on including of «Kemerova village settlement (XVIII - early XX century AD)» into the List of found objects of celtural heritage.

\section{References}

Chernaia, M.P. (1992). Tomskaia krepost' XVII v. po arkheologicheskim istochnikam [Tomsk fortress of the $17^{\text {th }}$ century based on archaeological sources]. In Voprosy etnokul'turnoi istorii narodov Zapadnoi Sibiri [Issues of the ethnic and cultural history of the Western Siberia population]. Tomsk: Tomsk State University, 57-77.

Chernaia, M.P. (1997). Rekonstruktsiia oboronitel'nych sten Tomskogo kremlia serediny XVII v. [Reconstruction of the defensive walls of the Tomsk town fort of the mid-17 th century]. In Aktual'nye problemy drevnei i srednevekovoi istorii Sibiri [Topical issues of ancient and medieval history of Siberia]. Tomsk: Tomsk State University, 327-343.

Chernaia, M.P. (2015). Voevodskaia usad'ba v Tomske. 1660-1760-e gg.: istoriko-arkheologicheskaia rekonstruktsiia [Voivode's House in Tomsk. 1660-1760s: historical and archaeological reconstruction]. Tomsk, Izdatel'skii dom D-Print, 276 p.

Elert, A. Kh. (1988). Istoriko-geograficheskoe opisanie Tomskogo uezda G. F. Millera (1734 g.) [Historical and geographical description of Tomsk Uezd by G. F. Müller (1734)]. In Istochniki po istirii Sibiri dosovetskogo perioda [Sources on the pre-Soviet history of Siberia]. Novosibirsk, Nauka, 59-101.

Kovtun, I.V. (2012). Proiskhozhdenie goroda Kemerovo [The origin of the city of Kemerovo]. In Istoriko-kul'turnoe nasledie Kuzbassa [Historical and cultural heritage of Kuzbass], 4, 20 -42. 
Mamontov, V.N. (1910). Kemerovskoe mestorozhdenie kamennogo uglia [The Kemerovo coal deposit]. Tomsk, [s. n.], 100 p.

Marochkin, A.G., German, P.V. (2011). K arkheologicheskoi karte iuzhnykh raionov Nizhnego Pritom'ia [To an archaeological map of the south of the Lower Tom' region]. In Istoriko-kul'turnoe nasledie Kuzbassa [Historical and cultural heritage of Kuzbass], 3, 78-86.

Marochkin, A.G., Plats, I.A., Kononchuk, K.V. (2015) Rezul'taty arkheologicheskoi razvedki 2015 goda v iuzhnykh raionakh Nizhnego Pritom'ia [The Results of the Archaeological Survey in the South of the Lower Tom' Region in 2015]. In Uchenye zapiski muzeia-zapovednika «Tomskaia Pisanitsa» [Transactions of Tomskaya Pisanitsa Museum-Reserve], 2, 58-66.

Marochkin, A.G., Iurakova, A. Iu., Shcherbakova, A.V., Plats, I.A., Fal'man, A.V., Kononchuk, K.V., Veretennikov, A.V. (2015). Raskopki poselencheskikh pamiatnikov na iuge Nizhnego Pritomia v 2015 godu [The Excavation of Settlement Sites in the South of the Lower Tom' Region in 2015]. In Uchenye zapiski muzeia-zapovednika «Tomskaia Pisanitsa» [Transactions of Tomskaya Pisanitsa Museum-Reserve], 2, 50-57.

Marochkin, A.G., Sizev, A.S., Plats, I.A., Kononchuk, K.V. (2017). Arkheologicheskaia razvedka v srednem i nizhnem techenii r. Tomi v 2016 g. [The Archaeological survey in the Middle and Lower Tom' Region in 2016]. In Uchenye zapiski muzeia-zapovednika «Tomskaia Pisanitsa» [Transactions of Tomskaya Pisanitsa Museum-Reserve], 5, 67-76.

Marochkin, A.G., Iurakova, A. Iu., Plats, I.A., Sizev, A.S., Veretennikov, A.V., Kononchuk, K.V., Shcherbakova, A.V., Minina, K.P., Fal'man, A.V. (2018). Itogi raskopok raznovremennogo pamiatnika Ivanovka-1 v nizhnemtomskom ochage naskal'nogo iskusstva (po materialam 2013-2018 gg.) [Results of Excavations on the Ivanovka-1 Multiple Period Site in the Lower Tom' Centre of Rock Art (based on the materials of 2013-2018)]. In Uchenye zapiski muzeia-zapovednika «Tomskaia Pisanitsa» [Transactions of Tomskaya Pisanitsa Museum-Reserve], 8, 5-15.

Messerschmidt, D.G. (1962). Research trip through Siberia 1720-1727 [Forschungsreise durch Sibirien 1720-1727]. 1 (VIII). Berlin, Akademie-Verlag, 379 p.

Mogil'nikov, V.A. (1993). Kemerovo. Istoriia nazvaniia [Kemerovo. The history of the name]. In Russkaia rech' [Russian speech], 4, 122-131.

Okuneva, I.V. (2006). Poseleniia Srednego Pritom'ia: itogi rabot chozdogovornoi temy «Volna» [Settlements of the Middle Tom' region: the results of the work within the contract-funded project «Wave»]. In Arkheologiia Iuzhnoi Sibiri [Archaeology of Southern Siberia]. Кемерово. 24, 29-39.

Perevalov, V.A. (2003). Novye dokumenty o gornozavodskom dele na Urale i v Sibiri v pervoi chetverty XVIII v. (po materialam GASO) [New documents on mining practice in the Urals and in Siberia in the first quarter of the 18th century. (based on the materials of the Public Archive of Sverdlovsk Region)]. In Ural'skii istoricheskii vestnik [Ural historical journal], 9, 316-335.

Shirin, Iu.V. (1993). Arkheologicheskie pamiatniki g. Novokuznetska [Archaeological sites of the city of Novokuznetsk]. In Kuznetskaia starina [Kuznetsk Antiquity]. 1, 10--46.

Shirin, Iu.V. (2000). Poselencheskie i pogrebal'nye kompleksy rossiiskikh pereselentsev XVII-XVIII vekov v Kuznetskom krae [Settlements and burial complexes of Russian settlers of the $17^{\text {th }}-18^{\text {th }}$ centuries in Kuznetsk land]. In Russkie staozhily. Materialy III Sibirskogo simpoziuma «Kul'turnoe nasledie narodov Zapadnoi Sibiri» [Russian longtime residents. Proceedings of the 6th Siberian Symposium "Cultural Heritage of the Peoples of Western Siberia»]. Tobol'sk-Omsk, 441-443.

Shirin, Iu.V. (2003). Keramika XVIII v. iz dereven' v okresnostiach Kuznetska [Pottery of the $18^{\text {th }}$ century from villages in the vicinity of Kuznetsk]. In Kuznetskaia starina [Kuznetsk Antiquity], 5, 17-35.

Shirin, Iu.V. (2006). K problem etnicheskoi atributsii iuzhnosibirskikh arkheologicheskikh kompleksov novogo vremeni v zone passeleniia russkikh [To the ethnic attribution of the South Siberian archaeological complexes of the modern period in the Russian settlement zone] In Kuznetskaia starina [Kuznetsk Antiquity], 7, 25-36.

Shirin, Iu.V. (2010). Rezul'taty arkheologicheskikh razvedok v basseine r. Kondomy [The results of archaeological survey in the river Kondoma region]. In Iz Kuznetskoi stariny [From Kuznetsk Antiquity], $1,4-42$. 
Shirin, Iu.V. (2012). Arkheologicheskie raskopki na pamiatnike «Kuznetsk» v 2012 g. [Archaeological excavations on Kuznetsk site in 2012]. In Istoriko-kul'turnoe nasledie Kuzbassa [Historical and cultural heritage of Kuzbass], 4, 70-76.

Shirin, Iu.V. (2013). Rezul'taty arkheologicheskikh razvedok v basseine r. Uskat [The results of archaeological reconnaissance in the river Uskat region]. In Iz Kuznetskoi stariny [From Kuznetsk Antiquity], 4, 19-35.

Shirin, Iu.V. (2015). Arkheologicheskie razvedki na r. Tomi [Archaeological survey on the river Tom']. In Iz Kuznetskoi stariny [From Kuznetsk Antiquity], 6, 4-75.

Sizev, A.S. (2017). Russkaia arkheologiia Kuznetskogo Pritom'ia: istoria izucheniia, sovremennoe sostoianie i perspektivy [Russian Archaeology of the Kuznetsk Tom' River region: the History of Research, Current Condition and Prospects]. In Vestnik Kemerovskogo gosudarstvennogo universiteta [Bulletin of Kemerovo State University], 4, 90-98.

Sizev, A.S., Plats, I.A. (2018). Arkheologicheskie razvedki v Kemerovskom i Tisul'skom raionach Kemerovskoi oblasti v 2017 g. [The Archaeological surveys in Kemerovo and Tisul' Districts of Kemerovo Region in 2017]. In Uchenye zapiski muzeia-zapovednika «Tomskaia Pisanitsa» [Transactions of Tomskaya Pisanitsa Museum-Reserve], 7, 41-46.

Uskov, I. Iu. (2001). Kemerovo: formirovanie territorii i naseleniia oblastnogo tsentra [Kemerovo: the formation of the territory and population of the regional center]. Kemerovo, Kuzbassvuzizdat, $84 \mathrm{p}$.

Uskov, I. Iu. (2011). Kemerovo: rozhdenie goroda [Kemerovo: the birth of the city]. Kemerovo, Kuzbassvuzizdat, $351 \mathrm{p}$.

Ziniakov, N.M., Bashtannik, S.V., Sokolov, P.G., Savel'eva, A.S. (2009) Novye pamiatniki arkheologii na iuge Nizhnego Pritom'ia [New monuments of archaeological sites in the south of the Lower Tom' region]. In Vestnik Rossiiskoi akademii estestvennykh nauk (Zapadno-Sibirskoe otdelenie) [Bulletin of the Russian Academy of Natural Sciences (West-Siberian Branch)], 11, 234-244.

RGADA - Russian State Archive of Ancient Records

GASO - State Archive of the Sverdlovsk region. 